\title{
VEGETATION CHANGES VIEWED FROM POLLEN ANALYSIS IN RAROTONGA, SOUTHERN COOK ISLANDS, EASTERN POLYNESIA
}

\author{
Toshiyuki Fujiki ${ }^{1,2,3} \bullet$ Mitsuru Okuno ${ }^{1,4}$ - Hiroshi Moriwaki ${ }^{5}$ Toshio Nakamura ${ }^{6}$ Kei Kawai ${ }^{7}$ \\ Gerald McCormack $^{8} \cdot$ George Cowan $^{9} \cdot$ Paul T Maoate $^{10}$
}

\begin{abstract}
This study presents accelerator mass spectrometry (AMS) radiocarbon dates and pollen assemblages of 400-cm core sediments collected from the Karekare Swamp in Rarotonga, Southern Cook Islands, to investigate vegetation changes on the island, in particular those induced by human impacts. Eight ${ }^{14} \mathrm{C}$ dates of charcoal and higher plant fragment samples indicate that the sediments accumulated since $\sim 6.0 \mathrm{cal} \mathrm{kBP}$, with an apparent interruption of deposition (hiatus) from 130 to $132 \mathrm{~cm}$ in depth, corresponding to $\sim 2.8$ to $0.7 \mathrm{cal} \mathrm{kBP}$. The appearance of Chenopodiaceae pollen from upland weeds, and Cucurbitaceae and Vigna pollen grains from cultivated plants suggest that human influence existed in core sediments above $130 \mathrm{~cm}$ in depth. The increased abundance of Pandanus pollen and monolate-type fern spores also implies the existence of human activity.
\end{abstract}

\section{INTRODUCTION}

Pollen analysis is a useful tool for reconstructing the dynamics of plant communities. Previous studies of vegetation changes in Polynesia (South Pacific Ocean) include Ellison (1994), Kirch and Ellison (1994), Kirch (1996), and Peters (1998). Kirch and Ellison (1994) and Kirch (1996) focused on the decrease of Ficus and Arecaceae, and the increase of Pandanus tectorius, Cyclosorus interruptus, and Dicranopteris lineari that appeared between 2.5 and $1.8 \mathrm{kBP}(\sim 2 \mathrm{cal} \mathrm{kBP})$ in the pollen record from Mangaia, Cook Islands (Figure 1). They connected these vegetation changes with the settlement of Polynesians on the island.

To reveal vegetation changes on Rarotonga, Southern Cook Islands, we obtained a 400-cm sediment core from Karekare Swamp (1.65 m asl; $\left.0.114 \mathrm{~km}^{2}\right)$, on the northeastern part of the island (Figure 1) in August 2009. Accelerator mass spectrometry (AMS) radiocarbon dates were conducted of charcoal and higher plant fragments samples collected from the sediments. We also examined the pollen assemblages in these sediments. This article presents these data and discusses the past vegetation environment in Rarotonga.

\section{STUDY SETTING AND MATERIAL}

\section{Outline of Geology and Palynology in Rarotonga}

The island of Rarotonga is a Pliocene-Pleistocene volcanic complex (Thompson et al. 1998) with a maximum height of $652 \mathrm{~m}$ and a circumference of $32 \mathrm{~km}$, surrounded by a coral reef (Figure 1). A reef flat extends several hundred meters to the reef, and then slopes steeply into the deep water that

1. AIG Collaborative Research Institute for International Study on Eruptive History and Informatics (ACRIFIS-EHAI), Fukuoka University, 8-19-1 Nanakuma, Jonan-ku, Fukuoka 814-0180, Japan.

2. Present address: Department of Applied Science, Faculty of Science, Okayama University of Science, 1-1 Ridai-cho, Kita-ku, Okayama 700-0005, Japan.

3. Corresponding author. Email: fujiki@das.ous.ac.jp.

4. Department of Earth System Science, Faculty of Science, Fukuoka University, 8-19-1 Nanakuma, Jonan-ku, Fukuoka 814-0180, Japan.

5. Physical Geography Section, Faculty of Law, Economics and Humanities, Kagoshima University, 1-21-30 Korimoto, Kagoshima 890-0065, Japan.

6. Center for Chronological Research, Nagoya University, Furo-cho, Chikusa-ku, Nagoya 464-8602, Japan.

7. Research Center for the Pacific Islands, Kagoshima University, 1-21-24 Korimoto, Kagoshima 890-8580, Japan.

8. Natural Heritage Trust, Cook Islands, PO Box 781, Avarua, Rarotonga, Cook Islands.

9. The New Zealand Institute of Surveyors, PO Box 807, Rarotonga, Cook Islands.

10. Ministry of Infrastructure and Planning, PO Box 227, Rarotonga, Cook Islands.

Proceedings of the Radiocarbon and Archaeology 7th International Symposium

Ghent, Belgium, April 2013 | Edited by Mark Van Strydonck, Philippe Crombé, and Guy De Mulder

(C) 2014 by the Arizona Board of Regents on behalf of the University of Arizona 
surrounds the island (Moriwaki et al. 2006).

The island's interior is densely forested (jungle of ferns, creepers, and towering trees). Many endemic species are distributed on this island. The forests of Rarotonga are divided into three principal types (Merlin 1985): (1) the Homalium mountain forest; (2) the Fagraea-Fitchia ridge forest; and (3) the Metrosideros cloud forest. However, the coastal lowland and lower slope vegetation have been completely changed by human activities, and the secondary vegetation is composed mostly of species introduced from different areas. The lowland vegetation includes coconut plantations, secondary thickets and forests, and Dicranopteris fernland (Mueller-Dombois and Fosberg 1998).

Karekare is a back swamp, originated from doline (Moriwaki et al. 2006), bearing thick peaty deposits. Barringtonia asiatica, Pandanus tectorius, Hibiscus tiliaceus, and Cocos nucifera grow around the swamp. Herbaceous plants of Poaceae and Cyperaceae are flourishing in the swamp.

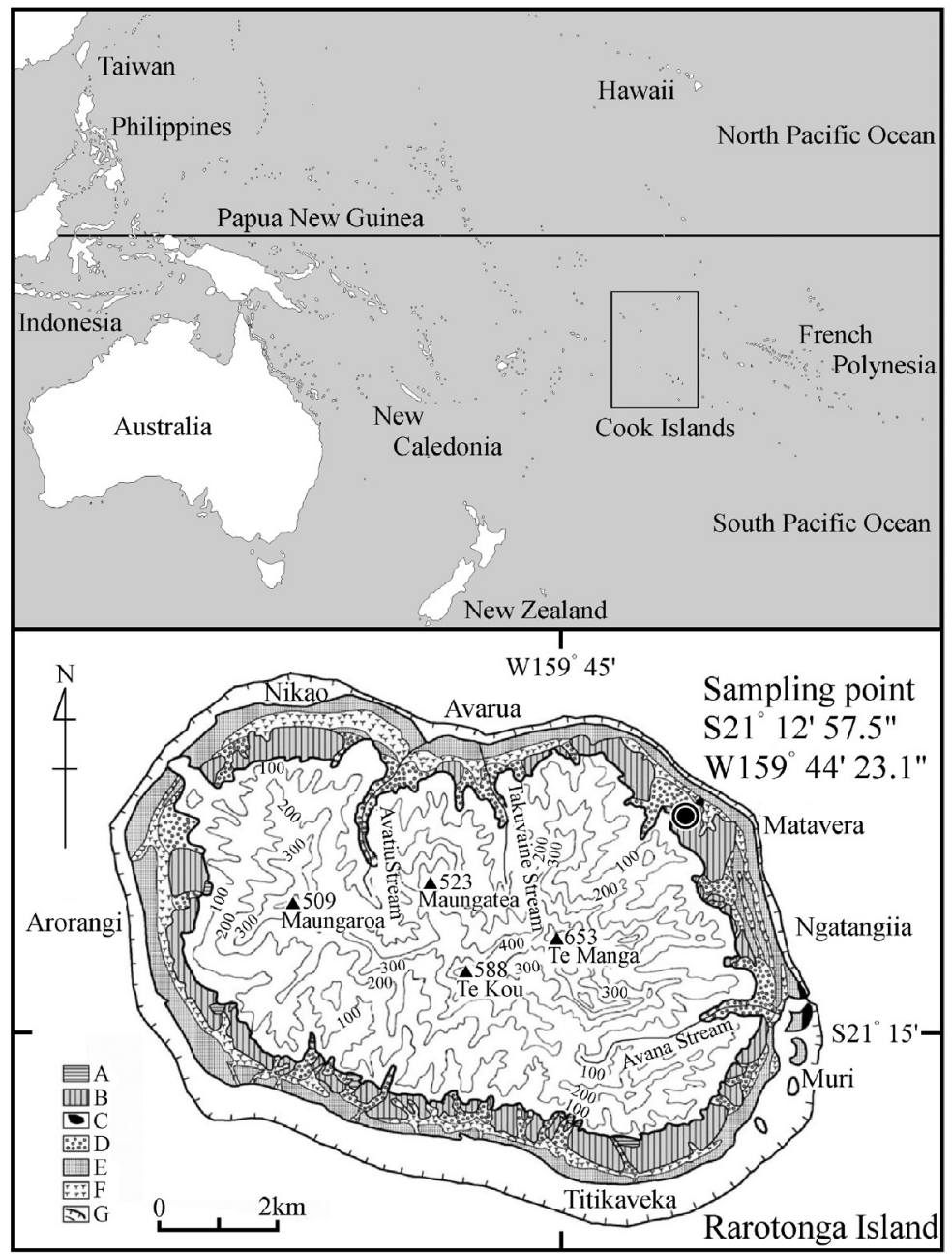

Figure 1 Index map showing the location of the Cook Islands (above). Geomorphologic map of Rarotonga (after Moriwaki et al. 2006) (below). A: Pleistocene upper terrace, B: Pleistocene lower terrace, C: Pleistocene coral reef, D: alluvial fan, E: sand ridge, F: swale and swamp, G: present coral reef. Counter lines in the mountain area are elevation in meters. The coring site in the Karekare Swamp is also indicated by the closed circle. 


\section{Study Site and Stratigraphy}

A $400-\mathrm{cm}$ long sediment core was obtained at the location of Karekare Swamp $\left(21^{\circ} 12^{\prime} 57.5^{\prime \prime} \mathrm{S}\right.$, $159^{\circ} 44^{\prime} 23.1^{\prime \prime} \mathrm{W}$ ) using a hand auger sampler. On the basis of sediment facies, the core can be divided into four layers: clayey peat from 0 to $137 \mathrm{~cm}$ depth below the ground surface; nondecomposed peat from 137 to $170 \mathrm{~cm}$; peat from 200 to $350 \mathrm{~cm}$; and clay from 350 to $400 \mathrm{~cm}$ (Figure 2).

Figure 2 Columnar section showing the stratigraphy of Karekare Swamp core.
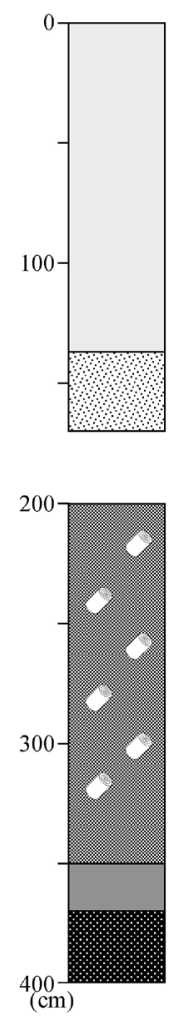

\section{ANALYTICAL METHODS}

\section{AMS Radiocarbon Dating}

Two charcoal and six higher plant fragment samples were collected from eight horizons immediately after coring. Ages of six samples (from depths of 60,130,132, 137, 140, $315 \mathrm{~cm}$ below surface) were measured by a HVEE tandetron accelerator mass spectrometry (AMS) system at Nagoya University (NUTA2; Nakamura et al. 2000) and ages of four samples (from depth of 130, 137, 200, $340 \mathrm{~cm}$ below surface) were obtained at the Institute of Accelerator Analysis Ltd. (IAAA), Japan. Samples suitable for ${ }^{14} \mathrm{C}$ dating could not be found in the sediments at the depth from 350 to $400 \mathrm{~cm}$ below the surface. The plant fragments could not be identified for all samples.

Samples were cleaned by routine acid-alkali-acid (AAA) treatments using $1.2 \mathrm{~N} \mathrm{HCl}$ and $1.2 \mathrm{~N}$ $\mathrm{NaOH}$, respectively, to remove carbonates and secondary organic acids. After washing with distilled water and drying, each pretreated sample was sealed in a quartz tube together with $\mathrm{CuO}$ and then heated. The gas product was cryogenically purified to $\mathrm{CO}_{2}$ gas using a vacuum line, and then reduced catalytically to graphite on Fe powder with $\mathrm{H}_{2}$ gas (Kitagawa et al. 1993). The three carbon isotopes in the samples and the NIST oxalic acid (HOxII) standard were measured with the AMS 
systems. The ${ }^{13} \mathrm{C} /{ }^{12} \mathrm{C}$ ratios $\left(\delta^{13} \mathrm{C}_{\mathrm{PDB}}\right)$ obtained by the AMS were used to correct carbon isotopic fractionation when calculating conventional ${ }^{14} \mathrm{C}$ ages. To estimate and remove the ${ }^{14} \mathrm{C}$ background level, the ${ }^{14} \mathrm{C}$ concentration of commercial graphite powder (dead carbon) was also measured in the same analytic sequence of sample and standard measurements.

\section{Pollen Analysis}

A few grams of sample were collected for pollen analysis from approximately every $10 \mathrm{~cm}$ of the core. Fossil pollen and spores were extracted by $10 \% \mathrm{KOH}$ treatment, $\mathrm{ZnCl}_{2}$ solution treatment, and Erdtman's acetolysis method (Erdtman 1934). To determine pollen assemblages, samples were dehydrated with an ethanol series $(30 \%, 60 \%$, and $99.5 \%)$ and then treated with xylene after acetolysis. The samples were mounted in Eukitt medium (O. Kindler GmbH \& Co, Freiburg, Germany) for observation under a light microscope (Kershaw et al. 1993; Coimbra et al. 2009). Five hundred or more pollen grains (excluding spores) were counted, including at least 300 arboreal pollen grains, in each sample. The percentage of each taxon (arboreal and non-arboreal pollen, and fern spores) was based on the total arboreal pollen count.

\section{RESULTS AND DISCUSSION \\ Depositional Age}

The results of AMS ${ }^{14} \mathrm{C}$ dating are shown in Table 1 and Figure 3. The ${ }^{14} \mathrm{C}$ dates were calibrated to a calendar age range with the SHCal04 data set (McCormac et al. 2004) using the computer program CALIB 6.0 (Stuiver and Reimer 1993; Stuiver et al. 2010). The obtained calendar ages are consistent with the stratigraphy of this core. However, a significant age gap is recognized at the depth between 130 and $132 \mathrm{~cm}$ below surface, likely due to an interruption in sedimentation (hiatus) at the site. The sedimentation rates of both parts were estimated to be $2.5 \mathrm{~mm} / \mathrm{yr}$ for 340 to $137 \mathrm{~cm}$ depth, $1.3 \mathrm{~mm} / \mathrm{yr}$ for 130 to $60 \mathrm{~cm}$ depth, respectively, based on modal points of calibrated probability distributions.

Regarding the causal mechanism for the interruption of sedimentation at this depth, some causes due to anthropogenic and environmental changes can be considered. The most plausible reason might be due to human impact. We suggest that the production of organic matter decreased for this reason, and the interruption of sedimentation occurred.

\section{Pollen Assemblages}

Forty-four varieties of fossil pollen grains and spores were detected. These were divided into AP (arboreal pollen; Figure 4), NAP (non-arboreal pollen; Figure 5), and FS (fern spores), as listed below:

AP: Pinus, Casuarinaceae, Ficus, other Moraceae, Castanopsis, Proteaceae, Elaeocarpus, Myrtaceae, Oleaceae, Barringtonia, Apocynaceae, Glochidion, Crtton, other Euphorbiaceae, Malvaceae, Wikstroemia, Gardenia, Mussaenda, other Rubiaceae, Erythrina, other Fabaceae, Araliaceae, Tristellateia, Rhizophoraceae, Arecaceae, Pandanus.

NAP: Poaceae, Cyperaceae, Urtica, Chenopodiaceae, Vigna, Cardiospermum, Onagraceae, Cucurbitaceae, Umbelliferae, Epilobium, Pharbitis, Valerianaceae, Campanulaceae, Artemisia, other Compositae, Nymphaeaceae.

FS: monolete type, trilete type.

Barringtonia, Arecaceae, and Pandanus pollen grains dominated in arboreal pollen. Barringtonia pollen is dominant in the cored sediments deeper than $140 \mathrm{~cm}$, and the abundance of this fossil 
Table 1 Results of AMS ${ }^{14} \mathrm{C}$ dating.

\begin{tabular}{|c|c|c|c|c|c|}
\hline $\begin{array}{l}\text { Depth } \\
(\mathrm{cm})\end{array}$ & Material & $\begin{array}{l}\delta^{13} \mathrm{CPDB} \\
(\%)\end{array}$ & $\begin{array}{l}{ }^{14} \mathrm{C} \text { date } \\
(\mathrm{BP})\end{array}$ & Lab code & $\begin{array}{l}\text { Age range (cal BP) } \\
(2 \sigma \text { probability } \%)\end{array}$ \\
\hline 60 & Charcoal & -23.1 & $365 \pm 25$ & NUTA2-19299 & $315-465(100.0 \%)$ \\
\hline \multirow[t]{2}{*}{130} & \multirow[t]{2}{*}{ Charcoal } & -23.1 & $640 \pm 20$ & IAAA-120416 & $\begin{array}{l}546-570(30.0 \%) \\
592-637(69.7 \%)\end{array}$ \\
\hline & & -23.4 & $680 \pm 25$ & NUTA2-19302 & 559-654 (100.0\%) \\
\hline 132 & Higher plant fragment & -25.4 & $2795 \pm 25$ & NUTA2-19301 & $\begin{array}{l}2762-2887(96.3 \%) \\
2907-2922(3.7 \%)\end{array}$ \\
\hline \multirow[t]{2}{*}{137} & Higher plant fragment & -26.1 & $3740 \pm 30$ & IAAA-120417 & $\begin{array}{l}3903-4095(94.4 \%) \\
4118-4154(5.6 \%)\end{array}$ \\
\hline & & -25.4 & $3745 \pm 25$ & NUTA2-19301 & $\begin{array}{l}3916-4095(94.0 \%) \\
4118-4146(6.0 \%)\end{array}$ \\
\hline 140 & Higher plant fragment & -24.9 & $3705 \pm 25$ & NUTA2-19303 & $\begin{array}{l}3877-3882(0.8 \%) \\
3886-4084(99.2 \%)\end{array}$ \\
\hline 200 & Higher plant fragment & -29.2 & $3990 \pm 30$ & IAAA-120418 & $\begin{array}{l}4246-4444(92.4 \%) \\
4481-4513(7.6 \%)\end{array}$ \\
\hline 315 & Higher plant fragment & -26.6 & $4825 \pm 25$ & NUTA2-19304 & $\begin{array}{l}5333-5346(3.8 \%) \\
5352-5372(3.3 \%) \\
5463-5589(92.9 \%)\end{array}$ \\
\hline 340 & Higher plant fragment & -27.9 & $5240 \pm 30$ & IAAA-120419 & $\begin{array}{l}5768-5787(1.3 \%) \\
5792-5805(0.9 \%) \\
5890-6004(96.8 \%) \\
6085-6097(0.8 \%) \\
6163-6167(0.2 \%)\end{array}$ \\
\hline
\end{tabular}

pollen is $10-89 \%$. However, the amount of this pollen suddenly decreases in the sediments above $140 \mathrm{~cm}$, where the abundance ranges between 0.2 and $9 \%$. Arecaceae pollen is dominant with an abundance of $25-80 \%$ throughout all layers.

The abundance of Pandanus pollen is about $25 \%$ in the bottom layer of the core, but appears only sporadically between 315 and $147 \mathrm{~cm}$ depth. This pollen becomes more prevalent above $147 \mathrm{~cm}$, and the abundance is about $25 \%$. However, the abundance ratio of this pollen decreases again at the top of the section.

Casuarinaceae pollen appears only in the sediment shallower than $130 \mathrm{~cm}$, and Myrtaceae pollen appears only at the depth below $200 \mathrm{~cm}$. The abundance of Erythrina pollen is 2-9\% at $250 \mathrm{~cm}$ and from 130 to $50 \mathrm{~cm}$, and this pollen appears sporadically at other depths.

The percentage of the herbaceous fossil pollen grains, such as Poaceae and Cyperaceae, are high. The percentages of monolete-type and trilete-type fern spores are also high. The percentages of Poaceae and Cyperaceae pollen grains increase slightly above $220 \mathrm{~cm}$. Monolete-type fern spores increase slightly above $220 \mathrm{~cm}$, and then rapidly increase above $157 \mathrm{~cm}$. Chenopodiaceae, Vigna, and Cucurbitaceae pollen grains appear only in the upper $130 \mathrm{~cm}$ of the core. Onagraceae, Compositae, and Nymphaeaceae pollen grains show a tendency to increase in the upper part of the core. 


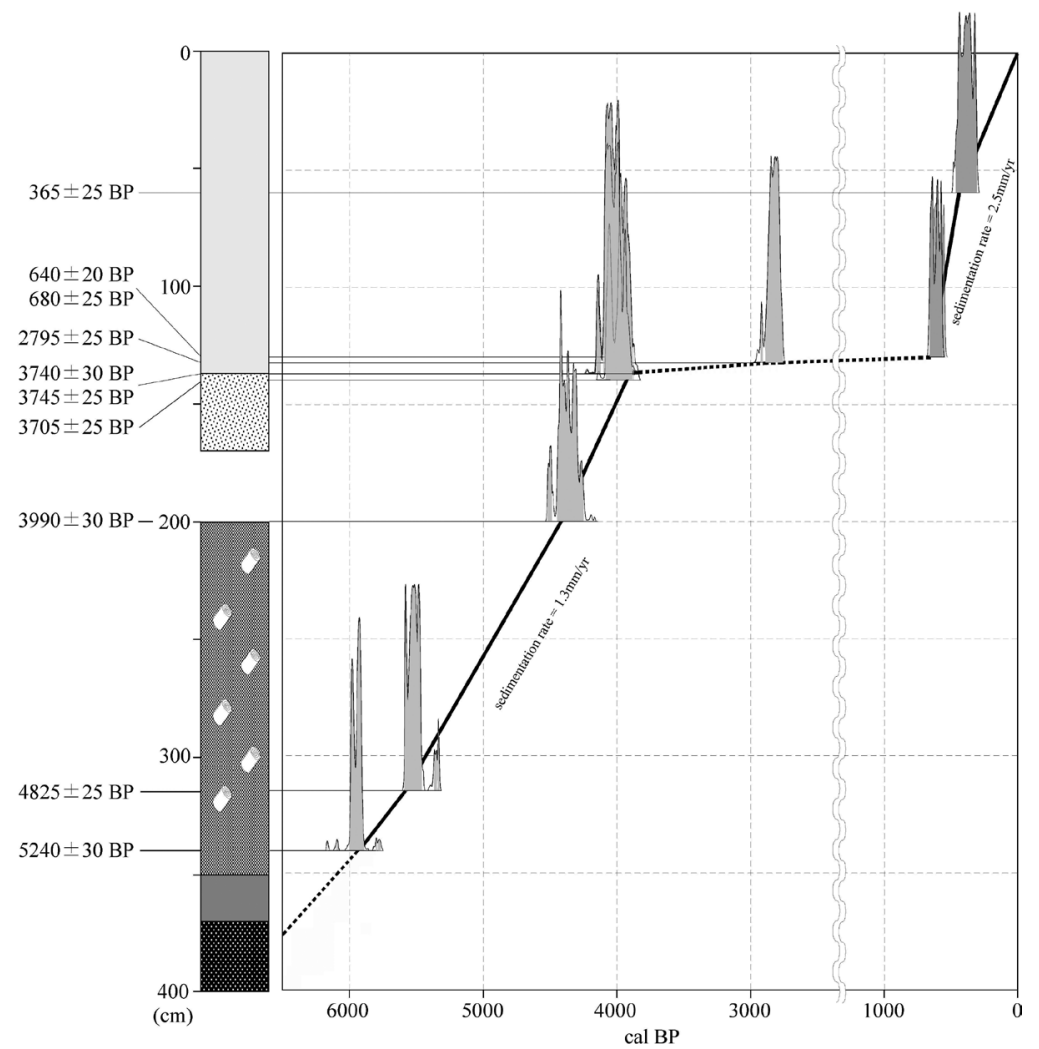

Figure 3 Age-depth profile of Karekare Swamp core. Histograms of the probability distribution for calibrated ${ }^{14} \mathrm{C}$ dates of the plant fragments from the swamp core are included.

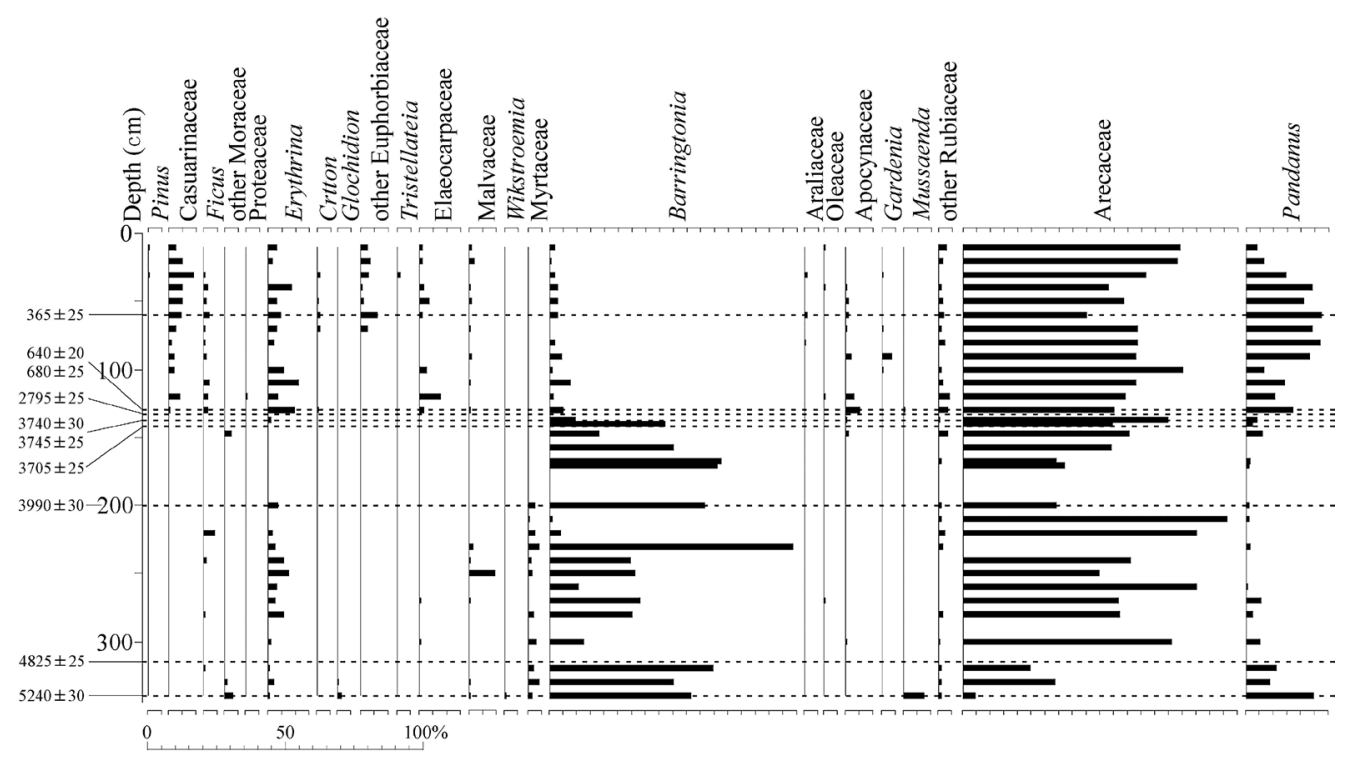

Figure 4 Arboreal pollen (AP) diagram for the Karekare Swamp core 


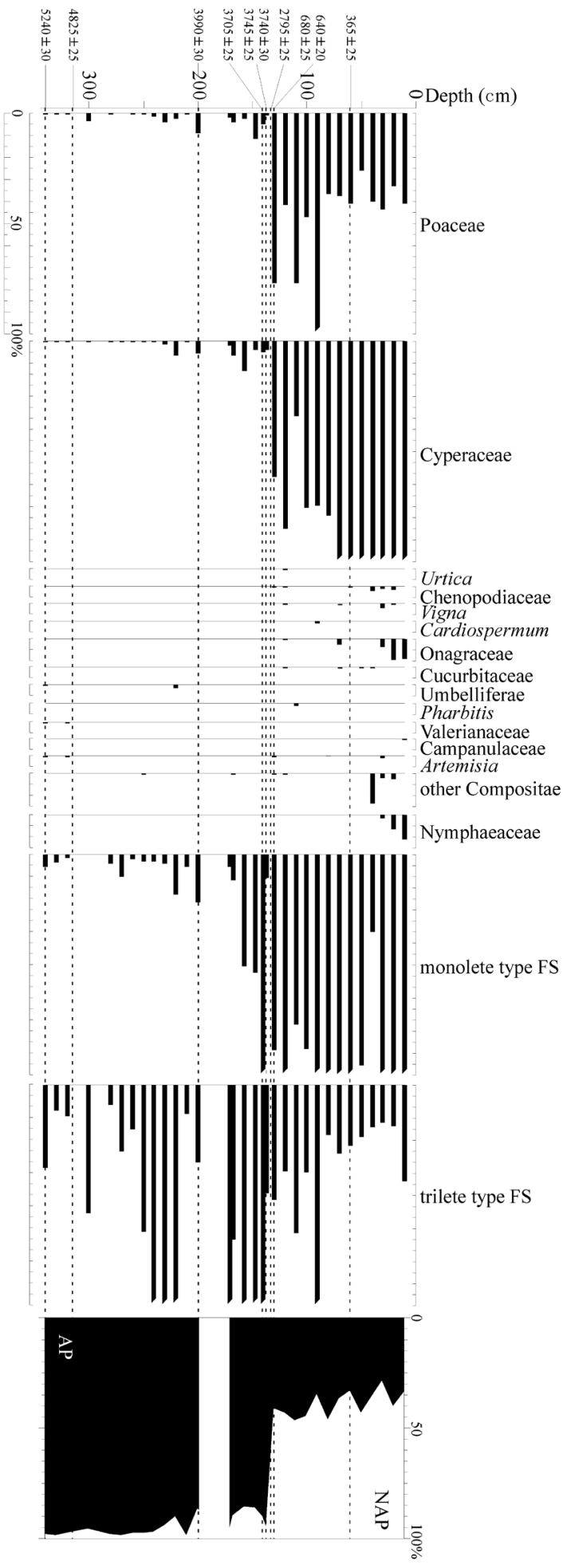

Figure 5 Non-arboreal pollen (NAP) diagram for the Karekare Swamp core. 

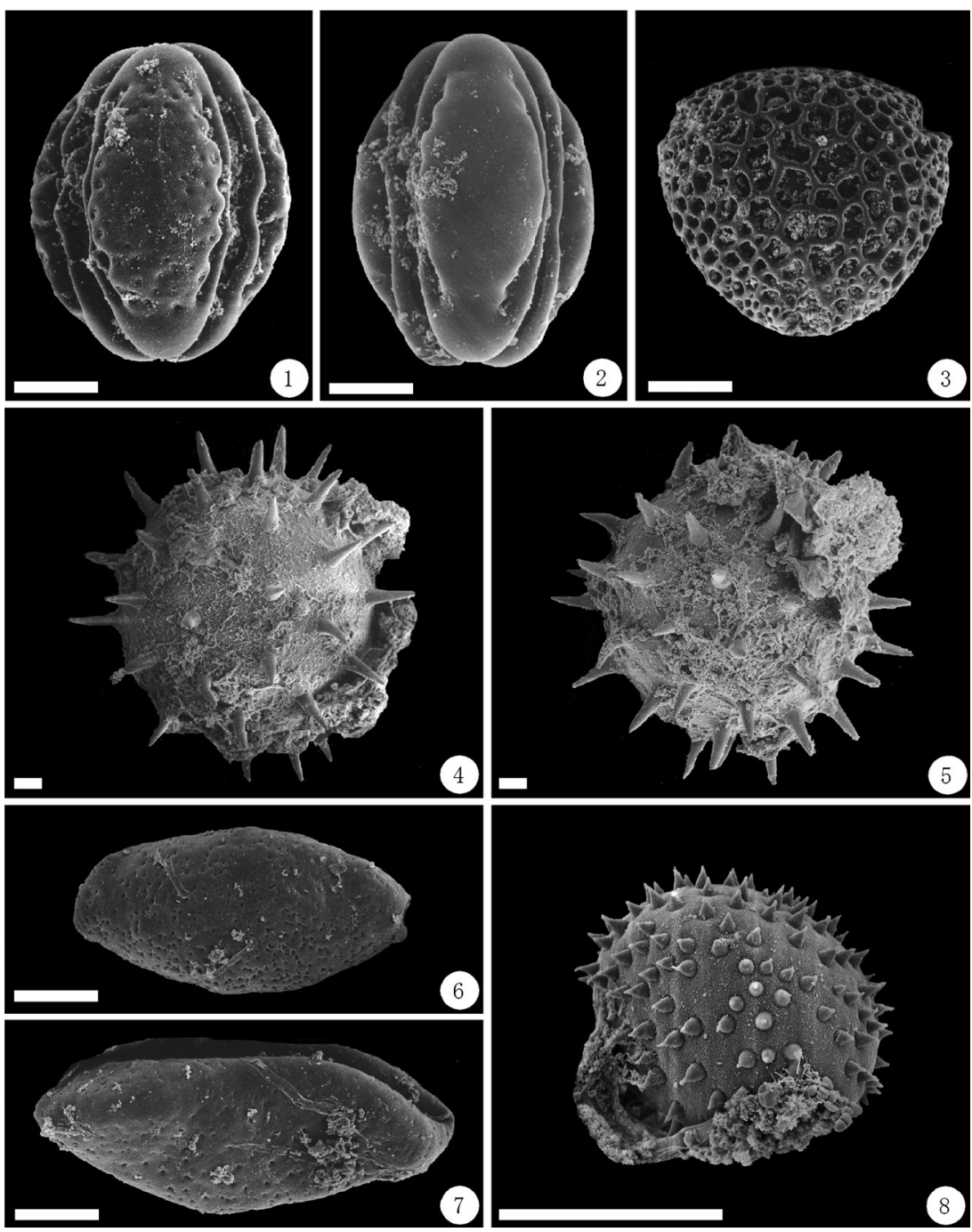

Figure 6 Selected SEM microphotographs of the fossil pollen found from Karekare Swamp core: 1-2: Barringtonia, 3: Erythrina, 4-5: Hibiscus, 6-7: Arecaceae, 8: Pandanus. Scale bar is $10 \mu \mathrm{m}$.

Barringtonia pollen decreases from $150 \mathrm{~cm}$, and decreases rapidly at $137 \mathrm{~cm}$. The dry field weed pollen grains, such as Chenopodiaceae, and the cultivated plant pollen grains, such as Vigna and Cucurbitaceae, are detected from $130 \mathrm{~cm}$.

Based on this evidence, humans seem to have been active there since about $0.7 \mathrm{kBP}(\sim 0.6 \mathrm{cal} \mathrm{kBP})$. Barringtonia asiatica is dominant along the coast of the Southern Cook Islands, including Rarotonga, Mangaia, and Atiu (Merlin 1985, 1991; Franklin and Merlin 1992). Thus, it is inferred that the $B$. asiatica forest was destroyed, after which herbaceous species, such as Poaceae, Cyperaceae, and fern, flourished. The grasslands and fernlands accompanied by Pandanus tectorius spread as the secondary vegetation. 
Tonga, Samoa, and other western Polynesian islands were colonized until $\sim 1000 \mathrm{BC}$ and the eastern Polynesian islands were settled until about AD 600 from the archaeological evidence (Kirch 2001). However, the paleoenvironmental evidence from Mangaia Island may indicate human impacts from 2.5 to $2.0 \mathrm{kBP}$ ( 2.5 to $1.9 \mathrm{cal} \mathrm{kBP}$ ) (Kirch 2001). The percentage of P. tectorius pollen and Dicranopteris linearis and Cyclosorus interruptus spores increased, and this phenomenon is associated with the settlement of Polynesians on this island (Kirch and Ellison 1994; Kirch 1996). Regarding the paleoenvironmental evidence from Rarotonga Island, the percentage of monolete-type fern spores increased from $157 \mathrm{~cm}$, and the percentage of Pandanus pollen increased above $147 \mathrm{~cm}$ ( $4.0 \mathrm{cal} \mathrm{kBP})$. This vegetation change can be attributed to human impact. Therefore, there is a possibility that Polynesians settled in this island at $\sim 3.7 \mathrm{kBP}(\sim 4.0 \mathrm{cal} \mathrm{kBP})$. In the future, we plan to conduct further dating and study the pollen analysis in greater detail, in order to better estimate the arrival date of Polynesians to Rarotonga.

\section{CONCLUSIONS}

This article investigated the vegetation changes on Rarotonga, in particular, those induced by human impacts, using AMS ${ }^{14} \mathrm{C}$ dates and pollen analysis results of $400-\mathrm{cm}$ core sediments from the Karekare Swamp. The dry field weeds pollen grains, such as Chenopodiaceae, and the cultivated plant pollen grains, such as Vigna and Cucurbitaceae, are detected from $130 \mathrm{~cm}$. Thus, Polynesians reliably had been active there since $\sim 0.6 \mathrm{cal} \mathrm{kBP}$. Barringtonia pollen decreases from $150 \mathrm{~cm}$, monolete-type fern spores increased from $157 \mathrm{~cm}$, and Pandanus pollen increased from $147 \mathrm{~cm} . B$. asiatica forest was destroyed, after which the grasslands and fernlands accompanied by $P$. tectorius were established as the secondary vegetation in $\sim 4.0 \mathrm{cal} \mathrm{kBP}$.

\section{ACKNOWLEDGMENTS}

This work was partly supported by a Grant-in-Aid (20401004 and 21101002) for Scientific Research from the Japan Society for the Promotion of Science (JSPS) and the Ministry of Education, Culture, Sports, Science and Technology (MEXT), Japan. We wish to express our strong appreciation to Brenn Sarata (Fugro Engineers BV, The Netherlands) for her insightful comments on the draft paper.

\section{REFERENCES}

Coimbra S, Costa M, Jones B, Mendes MA, Pereira LG. 2009. Pollen grain development is compromised in Arabidopsis agp6 agp11 null mutants. Journal of Experimental Botany 60(11):3133-42.

Ellison J. 1994. Palaeo-lake and swamp stratigraphic records of Holocene vegetation and sea-level changes, Mangaia, Cook Islands. Pacific Science 48(1):1-15.

Erdtman G. 1934. Über die verwendund von essigsäureanhydrid bei pollenuntersuchungen. Svenska Botanica Tiddskrift 28:354-61.

Franklin J, Merlin M. 1992. Species-environment patterns of forest vegetation on the uplifted reef limestone of Atiu, Mangaia, Ma'uke and Miti'aro, Cook Islands. Journal of Vegetation Science 3(1):3-14.

Kershaw AP, McKenzie GM, McMinn A. 1993. A Quaternary vegetation history of northeast Queensland from pollen analysis of O.D.P. Site 820 . Proceedings of the Ocean Drilling Program Scientific Results 133:107-14.

Kirch PV. 1996. Late Holocene human-induced modifications to a Central Polynesian island ecosystem.
Proceedings of the National Academy of Sciences of the USA 93:5296-300.

Kirch PV. 2001. On the Road of the Winds: An Archaeological History of the Pacific Islands before European Contact. Berkeley: University of California Press. 424 p.

Kirch PV, Ellison J. 1994. Paleo-environmental evidence for human colonization on remote Oceanic Islands. Antiquity 68(259):310-21.

Kitagawa H, Masuzawa T, Nakamura T, Matsumoto E. 1993. A batch preparation method for graphite targets with low background for AMS ${ }^{14} \mathrm{C}$ measurements. Radiocarbon 35(2):295-300.

McCormac FG, Hogg AG, Blackwell PG, Buck CE, Higham TFG, Reimer PJ. 2004. SHCal04 Southern Hemisphere calibration 0-11.0 cal kyr BP. Radiocarbon 46(3):1087-92.

Merlin M. 1985. Woody vegetation in the upland region of Rarotonga, Cook Islands. Pacific Science 39(1):81-99.

Merlin M. 1991. Woody vegetation on the raised coral 
limestone of Mangaia, southern Cook Islands. Pacific Science 45(2):131-51.

Moriwaki H, Chikamori M, Okuno M, Nakamura T. 2006. Holocene changes in sea level and coastal environments on Rarotonga, Cook Islands, South Pacific Ocean. The Holocene 16(6):839-48.

Mueller-Dombois D, Fosberg FR. 1998. Vegetation of the Tropical Pacific Islands. New York: SpringerVerlag. $733 \mathrm{p}$.

Nakamura T, Niu E, Oda H, Ikeda A, Minami M, Takahashi $\mathrm{H}$, Adachi M, Pals L, Gottdang A, Suya N. 2000. The HVEE Tandetron AMS system at Nagoya University. Nuclear Instruments and Methods in Physics Research B 172(1-4):52-7.
Peters C. 1998. Human settlement, vegetation history and landscape change on Rarotonga, southern Cook Islands. Documenta Naturae 121:1-200.

Stuiver M, Reimer PJ. 1993. Extended ${ }^{14} \mathrm{C}$ data base and revised CALIB $3.0{ }^{14} \mathrm{C}$ age calibration program. $R a$ diocarbon 35(1):215-30.

Stuiver M, Reimer PJ, Reimer RW. 2010. CALIB 6.0. Available online at http:/calib.qub.ac.uk/calib. Accessed 2 April 2013.

Thompson GM, Malpas J, Smith IEM. 1998. Volcanic geology of Rarotonga, southern Pacific Ocean. New Zealand Journal of Geology and Geophysics 41(1): 95-104. 